\title{
The Effect of Pedagogic Competence, Professional Competence, Social Competence, and Teacher's' Personal Competence on Teachers' Performance in Marketing Program
}

\author{
Tri Sudarwanto and Raya Sulistyowati \\ Universitas Negeri Surabaya, Jl. Lidah Wetan, Surabaya (60213)
}

\section{Abstract}

Education is a human effort to expand knowledge in order to shape values, attitudes, and behavior. As a developing country, Indonesia needs a good quality in human resources. One effort to create quality human resources is through education. Schools as one of the formal education institutions have a very important role in realizing the goals of national education through the teaching and learning process. For this reason,

Corresponding Author:

Tri Sudarwanto

trisudarwanto@unesa.ac.id

Received: 29 January 2019

Accepted: 27 February 2019

Published: 24 March 2019

Publishing services provided by

Knowledge E

(c) Tri Sudarwanto and Raya

Sulistyowati. This article is

distributed under the terms of

the Creative Commons.

Attribution License, which

permits unrestricted use and

redistribution provided that the

original author and source are

credited.

Selection and Peer-review under the responsibility of the $3 \mathrm{rd}$ ICEEBA Conference Committee. the government is seeking quality education in Indonesia, especially formal education. Improving the quality of education in schools is directly related to students as learners and teachers as educators. One of the effort used to realize this goal is to improve teachers' performance.

\section{Introduction}

Teacher is not merely teacher who transfer knowledge, but also as educator who transfer values as well as mentor who influence and guide student in learning. For this reason the teacher is required to be professional in explaining the task. The effort to create a professional teacher, the government has made the requirements rules to become a teacher.

Teachers are required to have a good performance in order to create a good quality students. Mangkunegara (2000: 67) states that performance is the result of work in quality and quantity achieved by someone in carrying out their duties in accordance with the responsibilities that given to them.

Constitution No. 14 of 2005 Chapter IV Article 20 (a) about teacher and lecture stated that the teacher's work performance standard in carrying out his professional duties, the teacher is obliged to plan learning, carry out quality learning processes, assess and evaluate learning outcome. The principal task of the teacher is realized in teaching and learning activities and is a form of teacher performance. In Government Regulation 
(PP) Number 19 of 2005 concerning The National Education Standards Agency (BSNP) emphasized that educator (teacher) must have the competence as learning agent at the primary and secondary education levels and early childhood education.

The issuance of RI constitution number 20 of 2003 concerning the national education system article 42 indicate that educator must have minimum qualification and certification in accordance with the level of authority to teach, physically and spiritual healthy, and have the authority to realize national education goals. The effort that is carried out in stages by the government is to improve and improve human resources, by providing opportunities for teachers who do not have bachelor degree (S1) or equivalent to D4 to go back to college to improve their competence.

The competencies that possessed by each teacher will show the quality of the teacher in teaching. These competencies will be realized in the form of knowledge and professional mastery in carrying out their function as teacher (Majid, 2005: 6). Competence can be increase by adding knowledge and insight.

In line with the above thought, the authors are interested in further examining the competence of teachers on their performance with the formulation of the problem of how the influence of pedagogic competence, social competence, professional competence and teacher personality competence on teacher performance.

\section{Method}

The type of this research is survey research. Survey research is research conducted on large and small population, but the data studied is data from sample that taken from the population, so that relative event, distribution and relationship between variables are found. Data collection in this study is using instruments in the form of questionnaire, documentation and quantitative data analysis which aims to test the hypothesis that has been set.

The population in this study were all Vocational High School Marketing Program teachers. The method for sampling using purposive sampling technique is the sample used if in an effort to obtain data about the problem under study requires a data source that has specific criteria based on a particular assessment (Sugiana, 2008). The object of the sample is 20 professional teachers because it corresponds to the variables to be studied.

The independent variable $(X)$ in this study is pedagogic competence, personality competence, social competence and professional competence. The dependent variable in this study is teacher performance $(Y)$. Data collection methods used in this study are the 
distribution of questionnaires, observation and literature studies which are then tested by validity testing and reliability testing using SPSS.

Data analysis method that use in this study is multiple linear regression analysis with the equation:

$$
Y=a+b 1 X 1+b 2 X 2+b 3 X 3+b 4 X 4 .
$$

Description

$\mathrm{Y}=$ Teacher Performance

$\mathrm{X} 1=$ Pedagogic competence

$\mathrm{X} 2$ = Personality competence

X3 = Social competence

X4 = Professional competence

$\mathrm{a}=$ Parameters Constant

b1, b2, b3, b4 = Estimating Parameters

Source: Sugiyono (2006: 243)

Hypothesis testing used in this study includes:

1. Partial influence of $X 1, X 2, X 3$, and $X 4$ (t-test).

2. The influence of $\mathrm{X} 1, \mathrm{X} 2, \mathrm{X} 3$, and $\mathrm{X} 4$ on $\mathrm{Y}$ simultaneously ( $F$-Test)

If the magnitude of the significance probability is less than $0.05, \mathrm{Ha}$ is accepted, whereas if the significance probability is greater than $0.05, \mathrm{Ha}$ is rejected.

\section{Result and Discussion}

The development of competency was carried out to see the performance of teachers in carrying out their main tasks, namely carrying out learning, mentoring and/or implementing other tasks that relevant to school/madrasah functions. The results are used to assist teachers in increasing their knowledge and skills in certain competencies as needed. Thus, the teacher is expected to be able to contribute optimally in an effort to improve the quality of student learning and at the same time help the teacher in the development of his career as a professional.

Based on the results of the classic assumption test that has been done, it can be said that the equation model obtained has been included in the BLUE (Best Linear Unbias Estimator) category so that the model can be used to predict in this study. The equation shows that the direction of the line is formed linearly and is a positive line relationship. 
Or to put pedagogic competence, social, personality and marketing professionals on teacher performance is acceptable, with the magnitude of the influence known from the value of the simultaneous determination coefficient (R2) seen from the adjusted $R$ square column Model Summary table adjusted R square columns. In this study, the magnitude of adjusted $\mathrm{R}$ square is $0.762 \%$ or $76.2 \%$. It means that the amount of the contribution given by the teacher competence variable to the performance of the marketing teacher is $76.2 \%$ while the remaining $23.8 \%$ is explained by other variables not examined in this study. That there is an influence between the variables of pedagogic competence, social and professional personality to the marketing teacher's performance in more detail the similarity model contains the following meanings:

Constant $=37.060$. If the teacher's competency is 0 , then the marketing teacher's performance is 37.060 , while to find out the magnitude of the influence of each variable using the partial determination coefficient value ( $r 2$ ) obtained from the table of coefficients in the partial correlation column which is squared and multiplied by $100 \%$.

The results of testing the hypothesis of the influence of competency on teacher performance using a partial test, a significance value of $0.000<0.05$ was obtained. So, the hypothesis that has coefficient $X=0.777$. Teacher competence increases 1 , then the performance of marketing teachers will experience an increase of 0.777 .

Based on the literature study on Adams and Dickey's views in his book Basic Principles of Student Teaching, it can be concluded that there are 13 roles of a teacher in the teaching process that demands various competencies and flexibility in teaching, namely:

1. Teacher as a teacher, delivering knowledge, who need skill in provide information to the class.

2. Teacher as mentor need to have the skill to lead the student groups.

3. Teacher as mentor need to have the skill to direct and encourage student learning activities.

4. Teacher as environmental regulator need to have the skill to prepare and provide learning tools and materials.

5. Teacher as participant, need to have the skill by providing advice, directing class thinking, and give an explanation.

6. Teacher as expeditor, need to have the skill to investigate the sources of society that will be used.

7. Teachers as planner, need to have the skill to choose, and gather learning materials professionally. 
8. Teacher as supervisor need to have skill in supervising student's activities and class order.

9. Teacher as a motivator, necessarily have the skill to encourage student motivation.

10. Teacher as the questioner need to have questioning skill that stimulate the class to think and how to solve problem.

11. Teacher as instructor, need to have skill in how to reward student who get an achievement.

12. Teacher as evaluator, need to have the skill to assess student objectively, continuously, and comprehensively.

13. Teacher as counselor need to have the skill to help student who experience certain difficulties.

\section{Conclusions}

Based on the results of the research and discussion outlined, the conclusions of this study are:

1. The Importance of Teacher Competence

Problem of teacher professional competence is one of the competencies that must be possessed by every teacher in any level of education. Some things that cause the importance of teacher competence include:

(a) Teacher competency as a teacher selection tool.

(b) Teacher competency is important in the context of teacher development.

(c) Teacher competency is important in the context of curriculum development.

(d) Teacher competency is important in relation to student activities and learning outcomes.

2. Strategy to Improve Teacher Competence

In general, there are five tools that can be used to improve the competence of an organizational unit, namely:
(a) Buy
(b) Build
(c) Borrow 
(d) Bounce

(e) Blind

\section{References}

[1] Sugiyono. (2009). Metode Penelitian Pendidikan: Pendekatan Kuantitatif, kualitatif, dan R\&D. Bandung: Alfabeta.

[2] Usman, M. U. (2002). Menjadi Guru Profesional. Bandung: Remaja Rosdakarya. 